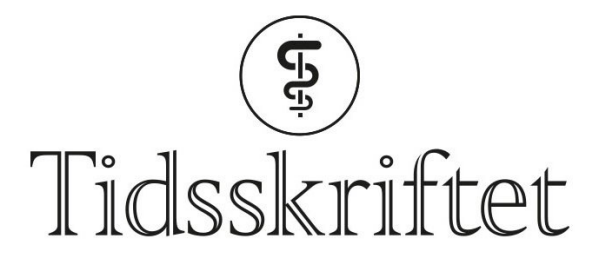

DEN NORSKE LEGEFORENING

\title{
Øyeblikkelig hjelp bør forkortes som $\emptyset$-hjelp
}

SPRÅKSPALTEN

KASHIF WAQAR FAIZ

E-post: kashiffaiz@gmail.com

Kashif Waqar Faiz er spesialist i nevrologi, ph.d. og master i helseadministrasjon.

I ordbøkene finnes det ingen anbefalt forkortelse for øyeblikkelig hjelp. Det trenger vi.

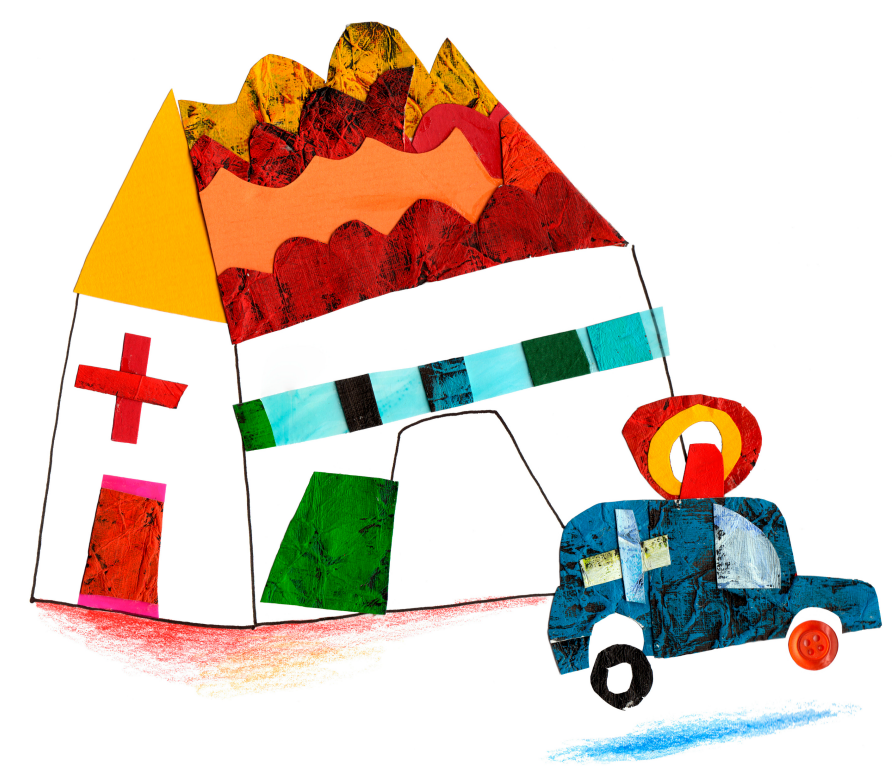

Illustrasjon: Science Photo Library/ NTB

Uttrykket øyeblikkelig hjelp brukes mye i helsetjenesten, men det har ingen anbefalt eller normativ forkortelse. Helsepersonelloven $\S 7$ definerer øyeblikkelig hjelp som helsehjelp som fremstår som påtrengende nødvendig (1), noe som i forarbeidene er beskrevet som «fare for liv eller fare for alvorlig forverring av en helsetilstand" (2). I klinisk praksis snakkes det om øyeblikkelig hjelp-pasienter og øyeblikkelig hjelp-innleggelser hvor man ikke kan vente med å vurdere om det foreligger alvorlig sykdom eller skade som krever rask behandling, som oftest under vurdering på legevakt eller i akuttmottak.

Et nettsøk viser at det finnes flere ulike varianter av forkortelser for øyeblikkelig hjelp: ø.hj., øhj, $\varnothing H J, \varnothing H, ø$-hjelp, Ø-hjelp og øhjelp. Ordbøkene gir ingen veiledning.

Hovedregelen er at forkortelser skal ha små bokstaver og punktum (3), det vil si heller ø.hj. enn øhj og ØHJ. Ø.hj. likner på andre vanlige forkortelser, som f.eks., bl.a. og d.d. Initialordet $\emptyset H$ brukes først og fremst i forbindelse med kommunale øyeblikkelig hjelp døgnopphold 
(ØHD) (4). Bokstavsammensetninger skal som regel ha bindestrek, og fellesnavn skal ha små bokstaver (5), det vil si heller ø-hjelp enn Ø-hjelp og øhjelp. Andre eksempler på vanlige bokstavsammensetninger er p-pille, e-post og $u$-land. Forkortelser brukes først og fremst $\mathrm{i}$ skriftspråket, men en del er også vanlige i talespråket, spesielt hvis de lar seg uttale som vanlige ord, som cand.med., hiv og kols.

Jeg foreslår at ø-hjelp brukes som den foretrukne forkortelsen for øyeblikkelig hjelp. Fordelen med ø-hjelp fremfor ø.hj. er at forkortelsen kan brukes både i skriftlig og muntlig kommunikasjon, og den vil være kjent for alle.

\section{LITTERATUR:}

1. LOV-1999-07-02-64. Lov om helsepersonell m.v. (helsepersonelloven). https://lovdata.no/dokument/NL/lov/1999-07-02-64 Lest 29.5.2020.

2. Ot.prp. nr. 13 (1998-99). Om lov om helsepersonell m v (helsepersonelloven). https://www.regjeringen.no/no/dokumenter/otprp-nr-13-1998-99-/id159428/?ch=1 Lest 29.5.2020.

3. Språkrådet. Forkortelser. https://www.sprakradet.no/sprakhjelp/Skriveregler/Forkortinger/ Lest 29.5.2020.

4. Faiz KW. KAD, ØHD eller KØHD? Tidsskr Nor Legeforen 2019; 139. doi:10.4045/tidsskr.18.0978. [CrossRef]

5. Korrekturavdelingen.no. Forkortelser: Hvordan skrive forkortelser? https://www.korrekturavdelingen.no/forkortelser.htm Lest 29.5.2020.

Publisert: 26. oktober 2020. Tidsskr Nor Legeforen. DOI: 10.4045/tidsskr.20.0488

(C) Tidsskrift for Den norske legeforening 2020. Lastet ned fra tidsskriftet.no 